The International Journal of Banking and Finance, Volume 9 (Number 4) 2012: pages 74-95

\title{
FINANCIAL INSTABILITY, UNCERTAINTY AND BANK LENDING BEHAVIOR
}

Vigneshwara Swamy and S. Sreejesh

Indian School of Business-Hyderabad, India

\begin{abstract}
"Why do banks squeeze their lending activity" is an oft-repeated question during the times of financial crisis. This study examines an emerging economy’s banking system, and contributes to the evolving body of literature on the topic by providing answers to what causes the sluggish bank credit during times of recession. By employing cointegration technique, the study shows that bank credit has a significant positive relationship with the borrowing activities of debt users of the banks, hence, as the contrary an inverse relationship with investment activity is evident during financial crisis. Accordingly, we suggest that banks could increase their lending by increasing the borrowings rapidly either from the Central Banks or from Government supported long term lending institutions during recessionary periods.
\end{abstract}

Key Words: Time series models, Financial markets, Interest rates, Bank lending, Financial crisis, Credit declines

JEL Classification: C22, D53, E43, E51, G21

\section{Introduction}

The 2007-8 global financial crisis also termed as 'the great recession' led to a grave banking panic and threw most of the economies of the world into severe recession. That crisis is attributed as having been caused by several factors. But only few of the factors are associated with the housing and credit markets, the two commonly-cited factors. Insinuated causes include the insolvency of homeowners to meet their mounting mortgage payments, unusually high levels of personal and corporate debt levels, foolhardy financial product innovation, the collapse of vital financial institutions and awful errors of judgment by credit rating agencies in the rating of structured products. Macroeconomic factors have also been added: monetary 
policy, excessive liberalisation, global trade imbalances and ineffective government regulation.

Without refuting the impairing effects of the above factors, we believe that the origins of the global financial crisis lie in the rational profit-seeking behavior of banks. Indeed, we consider that reason in the course of economic expansion is a vital cause behind the procyclical financial infirmity of any economic system given bank's heightened sensitivity to a financial shock.

The global financial crisis has spread across the world through a range of financial as well as real economy channels. Cross-border bank lending has also been one of the major financial channels through which stresses in the global financial system are and were spread to other emerging economies. While for some economies in Europe, the transmission conduit for the losses on account of toxic assets was obvious and thereby increased the fragility of bank balance sheets. However, for some Asian economies such as that of India, the story was a bit different as the exposure of their domestic banks was lot less limited to such international toxic assets. Yet even these economies with little exposure did experience a substantial slow down. Hence, toxic assets alone cannot explain the virility of the effect.

The connection of a recession to banking crisis is an intensely problematic research issue. The consequent fall in bank lending experienced in both the exposed or little exposed economies has key implications for growth. However, the sag in credit supply puts upward pressure on interest rate spreads, and thereby leads to an inordinate fall in lending than one might see in a typical recession. What makes the banks squeeze their lending activity during the crisis? It is an oft-repeated question, which deserves re-examination to find credible economic reason(s) applicable across diverse banking systems across the globe. The available literature, though throws up some interesting insights. We attempt to find some more answers from a rather relatively conservative banking system like that of an emerging economy in India. Indian banking similar to much of Asian banking is characterized by sizeable proportion of ownership under government control, and is distinct from the free market and widely-held banks of the Anglo-Saxon model.

This paper is one among the relatively small family of works that underline the relationship between bank behavior and financial instability. It aims to analyze how the financial crisis passed through the banks' lending behavior. Our endeavor in this study is to 
understand the impact of financial uncertainty and instability on banks' behavior on credits more specifically the effect of the crisis on the lending behaviour of the banks.

We begin by presenting in section 2, the theoretical framework illustrating the recent approaches on financial instability placing the banking system at the epicenter of analysis. We analyze more specifically how financial instability affects the bank's lending behavior during times of economic shocks or crisis. The methodology involving the data and its sources and research design explaining the empirical framework including how to estimate the impact of factors as is done in section 3. The results of the analyses of the findings are presented in section 4. The conclusion and policy implications are offered in section 5.

\section{Financial instability and Bank Lending behavior}

\subsection{Theoretical Framework}

Global financial system saw an extraordinarily high economic growth with abundant liquidity from 2001 to 2007. It is established empirically that the origins of the global financial crisis can be traced to the low interest rate policies adopted by the Federal Reserve and other central banks after the burst of the dot com bubble in October, 1999. An exhaustive summary of the events preceding and accompanying the global financial crisis is offered in Allen and Carletti (2010), Brunnermeir (2009), Greenlaw et al. (2008) and Taylor (2008). The sudden outbreak of financial crisis in September 2008 (the worst month) affected banks across the globe with uncertainty and resulted in instability in the markets for several years. Banks reacted to the crisis by reducing their lending exposure (Ivanshina and Scharfstein, 2008). This behavior is contrary because banks would be hesitant to cut their lending too drastically in view of their enduring relationships with the borrowers. If such relationships terminated suddenly, it would prove to be too costly in furthering their business in future (Rajan, 1992; Ongena, 1999). Further, Ralph de Haas and Neeltje van Horen (2009) have found that, during a financial crisis, arranging banks retain large portions of loans and forge more concentrated syndicates, signifying an heightened need to screen and monitor borrowers.

Few economists building their analysis on a variety of analytical tools and hypotheses have scrutinized the association between bank behavior and financial uncertainty. One school of thought emphasizes the crucial role of uncertainty and confidence in the emergence of an endogenous mechanism of financial instability impelled by the dynamics of asset prices and 
banking behavior. The most archetypal and leading work adopting this approach was the "financial instability hypothesis" of Hyman P. Minsky which, basing on the financial concept of economic fluctuations states that economy's inherent tendency to transform itself into an unstable financially fragile system is dependent on the naive interplay of the profit-seeking behavior of economic agents. In the Minskyan model of financial instability, the profitseeking behavior of banks in an uncertain decision-making environment leads them to such financial practices that stem out to a situation of escalating financial fragility.

Of late, macroeconomic models grounded on asymmetric information also single out the role played by banks at the core of the assessment of financial instability and contend that the crux of financial crises is in the vulnerabilities of the banking sector. Mishkin (1999a and 1999b) argues that increase in information asymmetry spawns ex ante a cumulative risk of adverse selection and produces ex-post a proliferation in moral hazard, which is coped by limiting credits by the financial intermediaries. As asymmetries of information are ubiquitous in financial markets, any crisis that escalates the asymmetries of information like impairing of banking or non-banking intermediaries’ balance sheets, escalating interest rates, fall in asset prices and compounding uncertainty would and must cause in a curtailment of credits. Another school of thought emphasizes that the balance-sheet exposures (Allen et al., 2002) like maturity mismatches, currency mismatches, capital structure problems and solvency issues could contribute to a currency and banking crisis.

An empirical study by Calomiris and Wilson (2004) look into the causal link from the escalating credit risk by way of decreased bank funding to lower credit supply. DemirgüçKunt, Detragiache and Gupta (2006) notice a similar kind of evidence for an extensive country sample. Besides limiting the risk of their asset portfolio, the authors observe that banks quite often build up their capital buffer to insulate depositors from credit risk. Because of such 'deleveraging', bank lending tends to moderate considerably during the times of financial crises (De Haas and Van Lelyveld, 2006).

\subsection{Financial Soundness}

One of the important sources of vulnerability that can lead to a financial crisis can be the weakness (such as a high level of short-term debt) in the financial structure of the economy i.e., the composition and the size of the assets and liabilities on the balance sheet. A financial crisis follows when the demand for financial assets of one or more sectors plummet and consequently the banking system fails to meet the outflows or may be unable to attract new 
financing or roll over existing short-term liabilities. In this direction, financial soundness (Table-1) matters much during the financial crisis because it gives some indication of how likely it is that financial problems would be transmitted into the real economy (by, for example) a reduction in the supply of loans.

Table 1: Core financial soundness indicators of selected countries (percent)

\begin{tabular}{|c|c|c|c|c|c|c|c|c|c|}
\hline & Australia & France & UK & USA & Russia & China & India & Brazil & $\begin{array}{l}\text { South } \\
\text { Africa }\end{array}$ \\
\hline \multicolumn{10}{|c|}{ Capital Adequacy Ratio [CAR] } \\
\hline 2005 & 10.2 & 11.3 & 12.8 & 12.9 & 16.0 & 2.5 & 12.8 & 17.9 & 12.3 \\
\hline 2006 & 10.3 & 10.9 & 12.9 & 13.0 & 14.9 & 4.9 & 12.3 & 18.9 & 12.3 \\
\hline 2007 & 10.1 & 10.2 & 12.6 & 12.8 & 15.5 & 8.4 & 12.3 & 18.7 & 12.8 \\
\hline 2008 & 11.3 & 10.5 & 12.9 & 12.8 & 16.8 & 12.0 & 13.0 & 18.2 & 13.0 \\
\hline 2009 & 11.9 & 12.4 & 14.8 & 14.3 & 20.9 & 11.4 & 13.2 & 18.8 & 14.1 \\
\hline 2010 & 11.4 & 12.3 & 15.9 & 15.3 & 18.1 & 12.2 & 13.6 & 17.8 & 14.9 \\
\hline \multicolumn{10}{|c|}{ Non-Performing Assets [NPA] } \\
\hline 2005 & 0.6 & 3.5 & 1.0 & 0.7 & 2.6 & 8.6 & 5.2 & 3.5 & 1.8 \\
\hline 2006 & 0.6 & 3.0 & 0.9 & 0.8 & 2.4 & 7.1 & 3.3 & 3.5 & 1.1 \\
\hline 2007 & 0.6 & 2.7 & 0.9 & 1.4 & 2.5 & 6.2 & 2.5 & 3.0 & 1.4 \\
\hline 2008 & 1.3 & 2.8 & 1.6 & 3.0 & 3.8 & 2.4 & 2.3 & 3.1 & 3.9 \\
\hline 2009 & 2.0 & 3.6 & 3.5 & 5.4 & 9.5 & 1.6 & 2.3 & 4.2 & 5.9 \\
\hline 2010 & 2.2 & 4.2 & 4.0 & 4.9 & 8.2 & 1.1 & 2.4 & 3.1 & 5.8 \\
\hline \multicolumn{10}{|c|}{ Provisions to NPA s } \\
\hline 2005 & 17.6 & $\ldots$ & 54.0 & 154.8 & 176.9 & 24.8 & 60.3 & 179.7 & 59.4 \\
\hline 2006 & 17.6 & $\ldots$ & 54.6 & 134.8 & 170.8 & 34.3 & 58.9 & 179.9 & 54.5 \\
\hline 2007 & 18.3 & $\ldots$ & $\ldots$ & 91.7 & 144.0 & 39.2 & 56.1 & 181.9 & 44.9 \\
\hline 2008 & 21.9 & 70.0 & 38.1 & 74.4 & 118.4 & 116.4 & 52.6 & 189.0 & 31.4 \\
\hline 2009 & 22.6 & 63.2 & 41.1 & 57.7 & 95.8 & 155.0 & 52.1 & 156.7 & 29.6 \\
\hline 2010 & 22.0 & 62.3 & 35.4 & 64.2 & 103.7 & 218.3 & 51.5 & 171.1 & 32.6 \\
\hline \multicolumn{10}{|c|}{ Return on Assets [ROA] } \\
\hline 2005 & 1.8 & 0.6 & 0.8 & 1.8 & 3.2 & 0.6 & 0.9 & 3.0 & 1.2 \\
\hline 2006 & 1.7 & 0.6 & 0.5 & 1.8 & 3.3 & 0.9 & 0.9 & 2.7 & 1.4 \\
\hline 2007 & 1.6 & 0.4 & 0.4 & 1.2 & 3.0 & 0.9 & 0.9 & 2.9 & 1.4 \\
\hline 2008 & 0.9 & 0.0 & -0.4 & -0.1 & 1.8 & 1.0 & 1.0 & 1.4 & 2.1 \\
\hline 2009 & 1.0 & 0.4 & 0.1 & -0.1 & 0.7 & 0.9 & 1.1 & 1.9 & 0.9 \\
\hline 2010 & 1.2 & 0.6 & 0.2 & 0.9 & 1.9 & 1.0 & 1.1 & 2.1 & 1.0 \\
\hline \multicolumn{10}{|c|}{ Return on Equity [ROE] } \\
\hline 2005 & 25.6 & 11.8 & 11.8 & 17.8 & 24.2 & 15.1 & 13.3 & 29.8 & 15.2 \\
\hline 2006 & 27.8 & 14.0 & 8.9 & 17.2 & 26.3 & 14.9 & 12.7 & 27.6 & 18.3 \\
\hline 2007 & 30.2 & 9.8 & 6.2 & 11.2 & 22.7 & 16.7 & 13.2 & 28.9 & 18.1 \\
\hline 2008 & 18.9 & -1.0 & -10.3 & -1.6 & 13.3 & 17.1 & 12.5 & 14.9 & 28.7 \\
\hline 2009 & 17.4 & 8.2 & 2.6 & -0.6 & 4.9 & 16.2 & 13.1 & 20.4 & 15.8 \\
\hline
\end{tabular}




\begin{tabular}{|l|l|l|l|l|l|l|l|l|l|}
2010 & 20.5 & 13.3 & 3.9 & 8.2 & 12.5 & 17.5 & 12.5 & 21.7 & 14.7 \\
\hline
\end{tabular}

Data Source: IMF - All Countries FSI Data.

\subsection{Trends in Bank Credit}

Bank credit has shown a robust upward trend in most emerging economies until around 2007. One of the focal issues is the extent to which there was a decline in credit growth during the recession period and how it affected credit supply or demand. A decline in credit supply would imply that the impact of the crisis on the financial sector has swelled the effects of the very large cyclical downturn. On the contrary, if demand effects were cogent, this would indicate that efforts to supply financing and support the operation of the financial sector have been successful in boosting credit supply and mitigating the adverse effects of the crisis in developed financial markets. Growth in domestic credit in select economies particularly during the crisis period has nosedived in almost all the economies though the extent may vary (Figure 1). However, it is interesting that the experiences of BRICS countries are quite different form that of other developed countries in view of the nature of their economies.

Figure 1: Domestic credits of select economies over 2006-10 (Consolidated balance sheet of the banking sector)

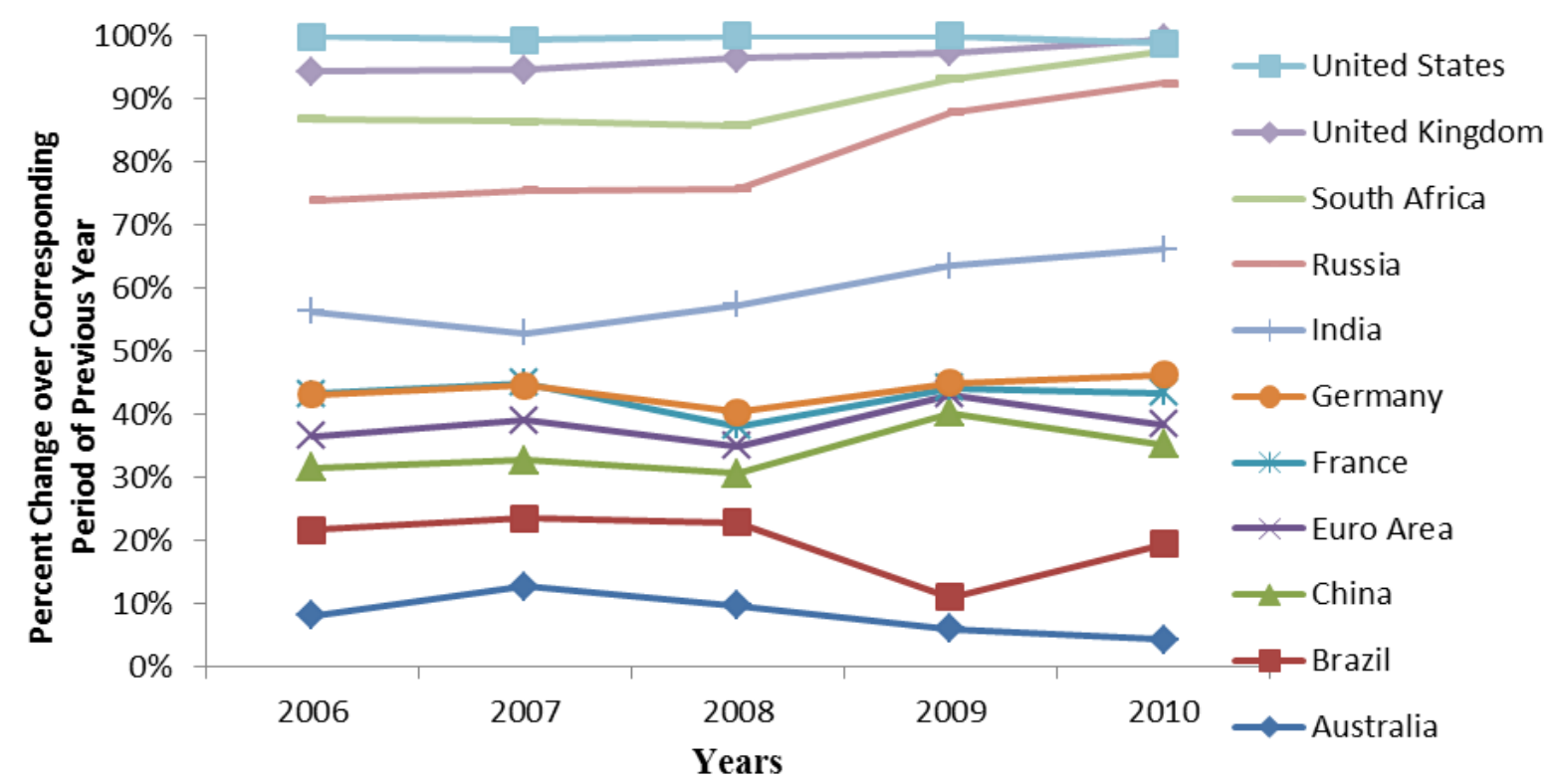

Source: IMF Dataset: Principal Global Indicators.

It is but natural to have our curiosity to understand the lending behaviour of the banks in such emerging economies, which showed some sense of resilience to financial crisis in view 
of their strong domestic demand, led growth. We examine the trend of bank credit in India, which is representative of a rather domestic focused banking sector when compared to other developed markets. The trend of bank credit in India even during the crisis period has experienced an upward trajectory despite huge constraining factors (Figure 2).

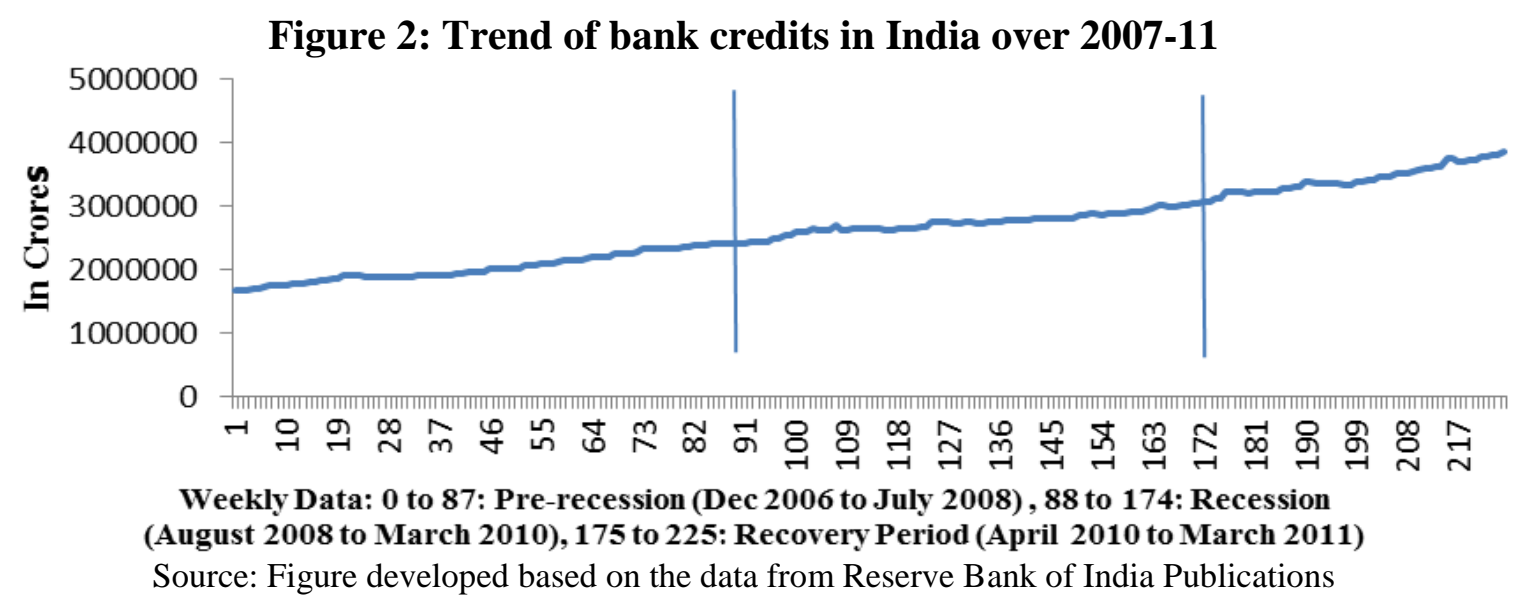

Banking sector being an integral part of the economy in ensuring the efficient transmission of the funds, it has a close relationship with the other macro-economic factors that play a vital part in the economic development. Despite the downward movement of some of the economic indicators like the imports and exports, the bank credit has continued to show rising trend in view of the strong domestic demand led growth (Figure 3).

Figure 3: Indian economic indicators over 2007-10

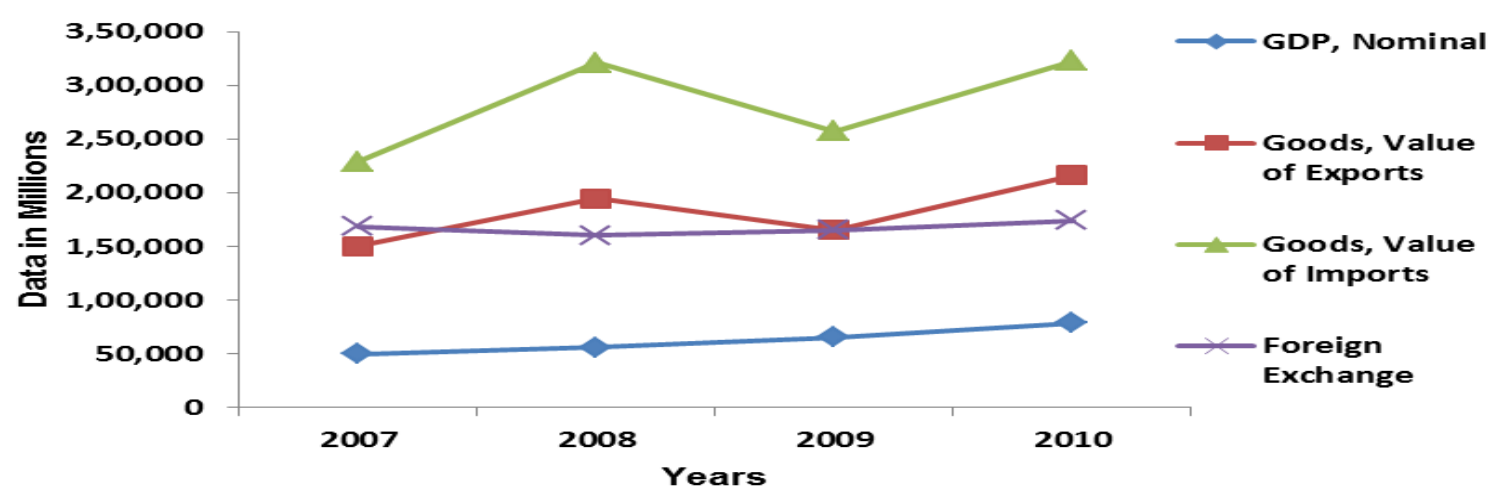

Data Source: International Financial Statistics (IFS) of IMF.

Further, the core financial selector indicators for India like; Capital Adequacy Ratio (CAR), Capital Adequacy Ratio-Tier-1, Gross Non-Performing Assets (GNPAs) to total loans, Net Non-Performing Assets (NNPAs) to total loans and Return on Equity (ROE) have 
experienced downward pressure during the recession period (Figure-4). On the contrary, liquid assets to total assets ratio has moved upwards indicating the tendency of the banks to hold cash during the times of recession instead of investing in loans or investment products.

Figure 4: Core financial sector indicators for India over 2008-10

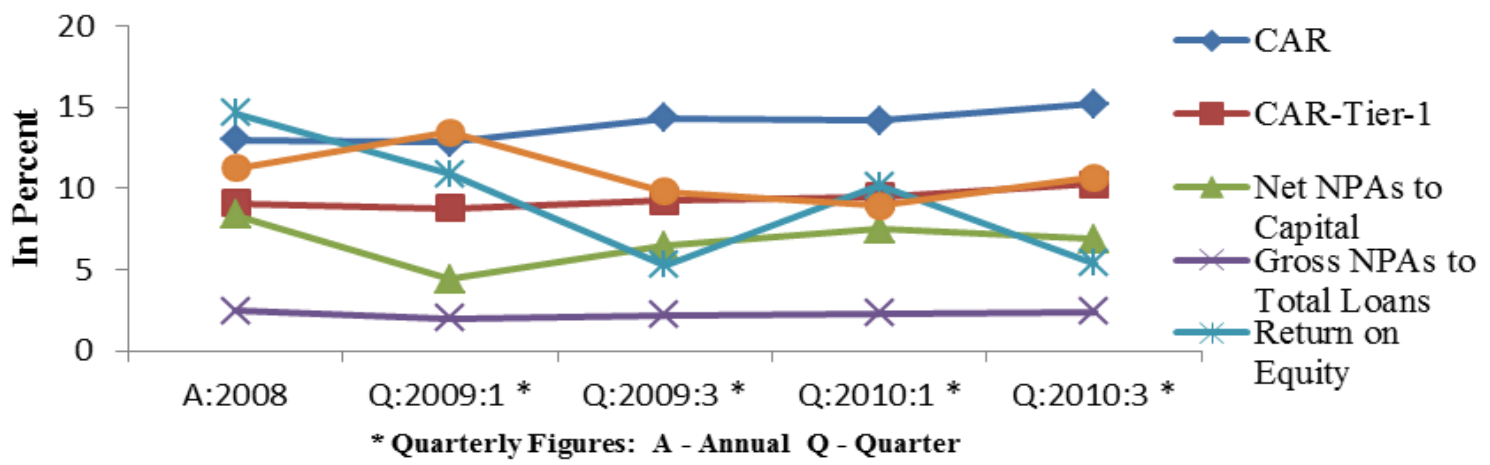

Data Source: International Financial Statistics (IFS) of IMF

Interest Rates (Benchmark prime lending rate), Money market rate and the discount rates) which have significant impact on the lending activity showed downward movement in the Indian banking scenario (Figure 5).

Figure-5: Interest rates in India over 2007-10

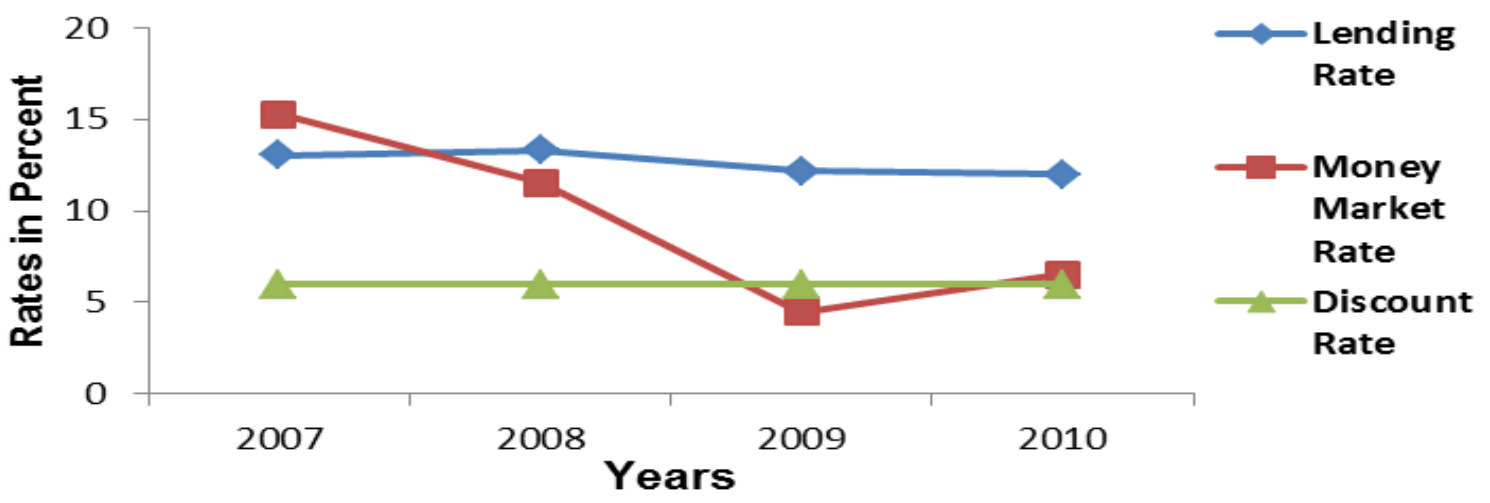

Data Source: International Financial Statistics (IFS) of IMF

Of course, banks claim that sluggish bank lending was due to a fall in demand but they have tightened the terms of credit on which borrowers can access funds. However, given the backdrop of the above discussed understanding of the behavior of the banking sector during the recession period, we try to find answer for our specific question, how was the lending behavior of the banks during the recession and which was the strongly correlated determinant for bank credits. 


\section{Empirical Framework and Estimation}

We use data on bank behavior in India to provide fresh insights into how banks respond to financial crises especially in the area of credit supply. The framework of our empirical analysis is based on a robust database and well-established techniques.

\subsection{Data and the Key Variables}

The weekly data on Commercial Banks in India for the study period has been sourced from the robust database of Reserve Bank of India (various issues of Statistical Tables Relating to Banks in India and Report of Trend and Progress of Banking in India).

Table 2: Definitions for key variables in our models

\begin{tabular}{|l|c|l|}
\hline \multicolumn{2}{|c|}{ Variable } & \multicolumn{1}{c|}{ Description } \\
\hline Bank Credit & LnBC & $\begin{array}{l}\text { Logarithm of Bank Credit (total of outstanding credit } \\
\text { for all the scheduled commercial banks in India) }\end{array}$ \\
\hline $\begin{array}{l}\text { Aggregate } \\
\text { Deposits }\end{array}$ & LnAD & $\begin{array}{l}\text { Logarithm of Aggregate Deposits (total of outstanding } \\
\text { aggregate deposits held by all the scheduled } \\
\text { commercial banks in India) }\end{array}$ \\
\hline Investments & $\begin{array}{l}\text { Logarithm of Investments (total of outstanding } \\
\text { investments by all the scheduled commercial banks in } \\
\text { India) }\end{array}$ \\
\hline $\begin{array}{l}\text { Money at Call } \\
\text { and Short Notice }\end{array}$ & LnMATCAL & $\begin{array}{l}\text { Logarithm of Money at Call and Short Notice (total of } \\
\text { all Money at Call and Short Notice held by all the } \\
\text { scheduled commercial banks in India) }\end{array}$ \\
\hline Borrowings & LnBORROW & $\begin{array}{l}\text { Logarithm of Borrowings (total of all outstanding } \\
\text { Borrowings by all the scheduled commercial banks in } \\
\text { India) }\end{array}$ \\
\hline Bank Nifty & LnBNIFTY & $\begin{array}{l}\text { Logarithm of Bank Nifty index of NSE which is } \\
\text { considered to be most representative index for } \\
\text { understanding the market performance of banks in India }\end{array}$ \\
\hline Lending Rates & LnBPLR & $\begin{array}{l}\text { Logarithm of BPLR (Benchmark Prime Lending Rates) } \\
\text { rates which represent the average levels of bank lending } \\
\text { rates in India }\end{array}$ \\
\hline $\begin{array}{l}\text { Cash-Deposit } \\
\text { Ratio }\end{array}$ & $\begin{array}{l}\text { Ratio of Cash held by banks to their Aggregate } \\
\text { Deposits }\end{array}$ \\
\hline $\begin{array}{l}\text { Investment- } \\
\text { Deposit Ratio }\end{array}$ & $\begin{array}{l}\text { Ratio of outstanding Investments to Aggregated } \\
\text { Deposits of banks }\end{array}$ \\
\hline $\begin{array}{l}\text { Credit-Deposit } \\
\text { Ratio }\end{array}$ & $\begin{array}{l}\text { Ratio of Outstanding Credit to Aggregate Deposit levels } \\
\text { of banks }\end{array}$ \\
\hline
\end{tabular}


The choice of the period is made in line with the need of the study to compare and analyze the impact of financial crisis on the bank lending activity. Accordingly, we have set three distinct comparable time horizons keeping in mind the availability of the weekly data. Phase-1 covers the period from Dec 2006 to July 2008 to represent the pre-recession (boom/normal) period, Phase-2 covers the period from August 2008 to March 2010 to represent the recession period and finally the Phase-3 includes the period from April 2010 to March 2011 to capture the recovery period. Further, the variables used for the analysis include important determinants of bank behavior and are detailed in Table 2.

Credit to Deposit Ratio (CDR) is one of the indicators that is used to measure / reflect the bank/s' efficiency in credit delivery. A careful look at its trend gives a broader trend of the banks' credit supply activity. Though this ratio involves the outstanding levels, it captures the inclusive picture of the credit delivery activity. Figure 6 captures the volatile movement of CDR during the study period. During the recession period, the CDR has experienced an uncertain downward tumble and has found an upward pitch during the subsequent recovery period.

Figure 6: Trend of credit to deposit ratio over 2007-11

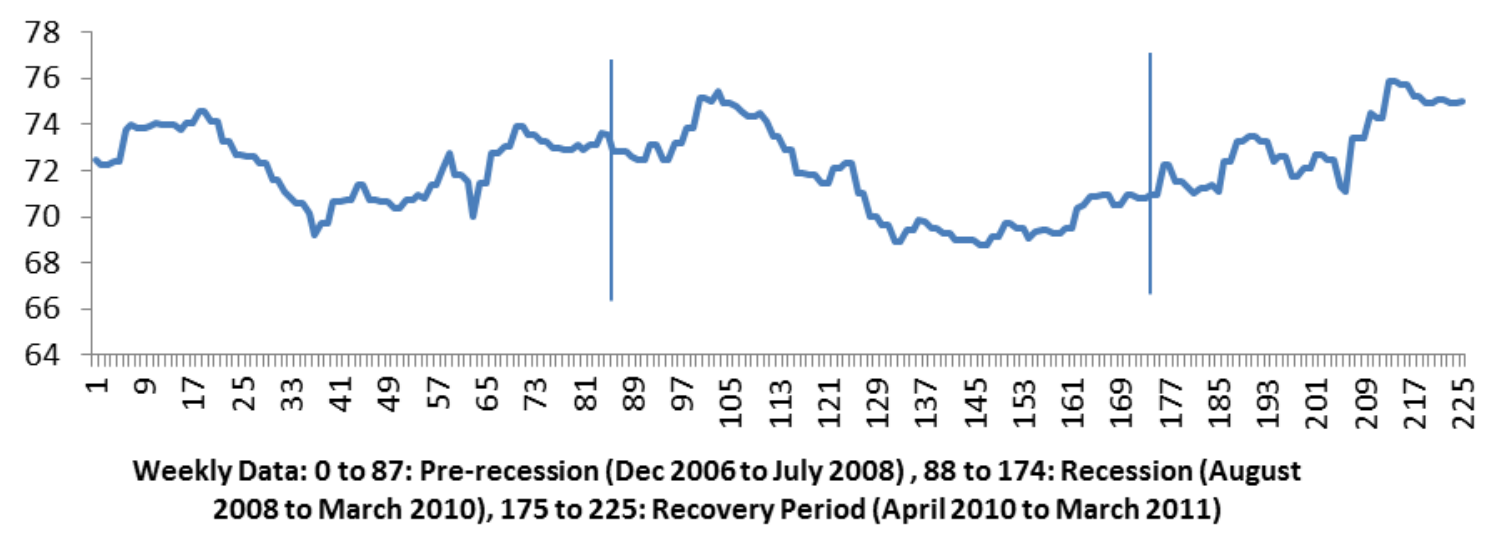

Source: Reserve Bank of India Database.

We look at the trend of Investment to Deposit Ratio (IDR) during the study period. Figure-7 presents the interesting movement of IDR wherein we notice that the movement is almost opposite to that of CDR during the recesssion period which indicates that banks were hesitant towards credit delivery and turned towards safe investment of their avaailable funds instead of the riskier lending activity. 
Figure 7: Trend of investment to deposit ratio in India over 2006-11

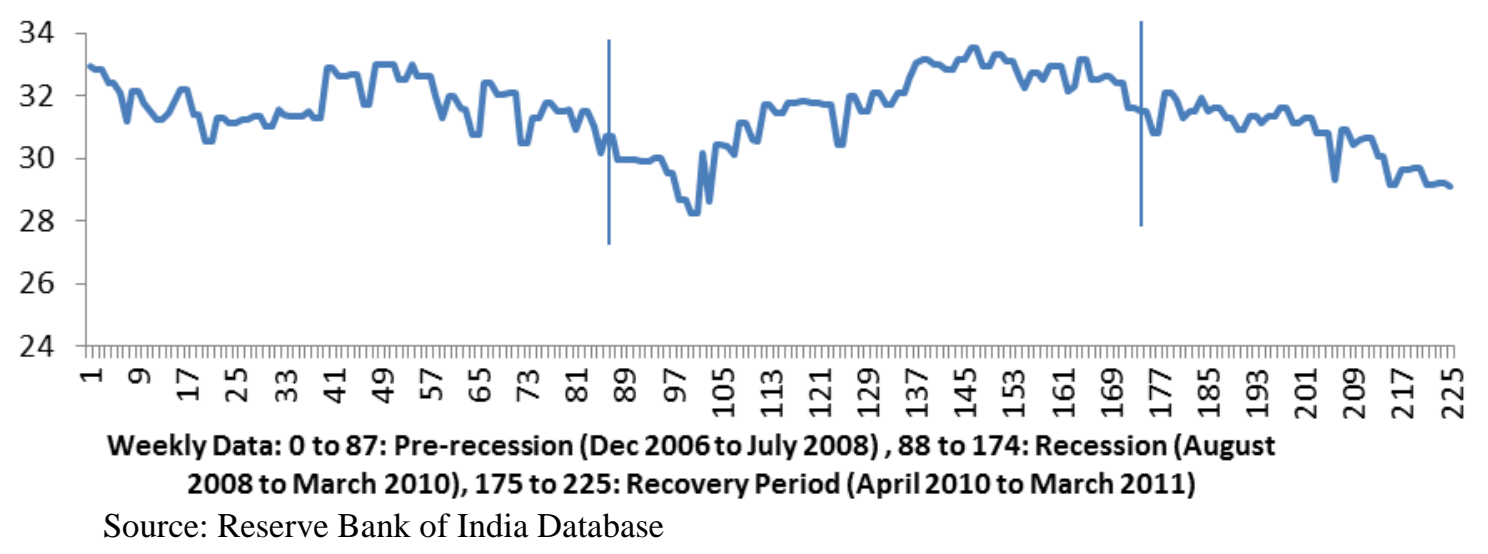

We take a look at the liquidity management of the banks during the study period and find that Cash to Deposit Ratio which indicates the cash holding levels of the banks was sliding down during the recession period (Figure 8). This denotes the tight funds mangement scenario during the recession period due to the impact of the crisis.

Figure 8: Cash to deposit ratio in India over 2006-11

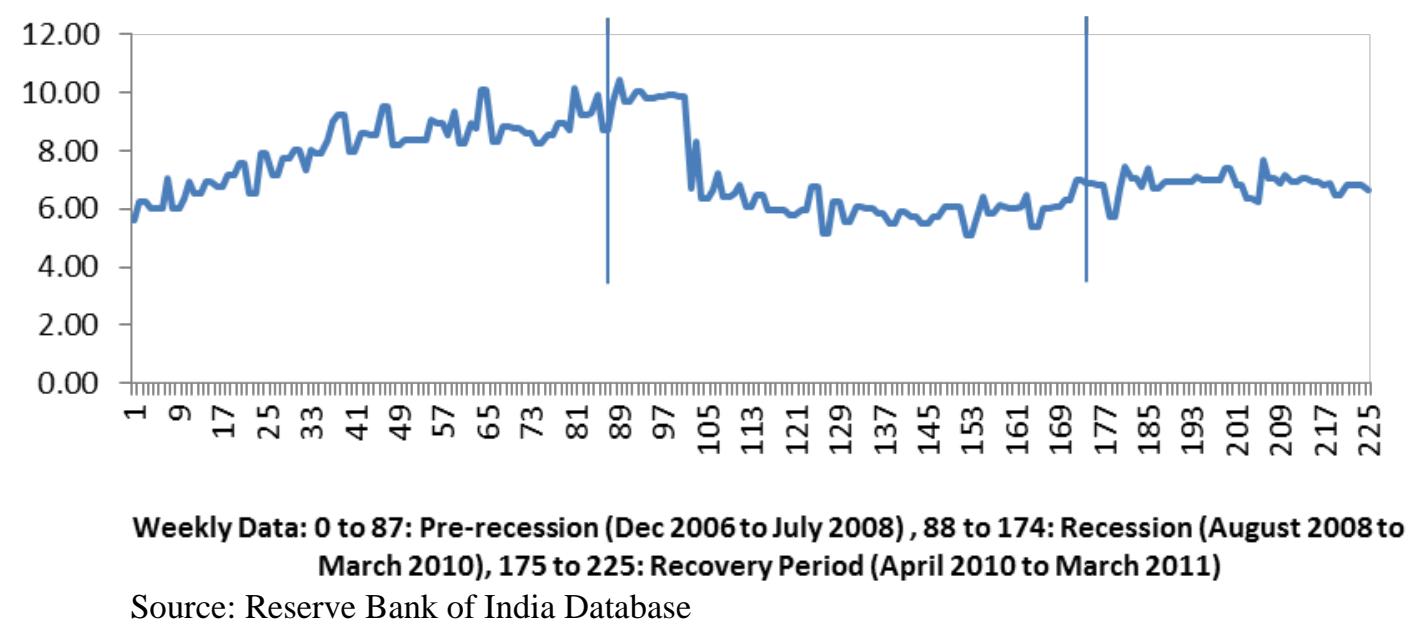

\subsection{The Model}

Bank Credit has direct relationship with the predictor variables such as Aggregate Deposits, Borrowings, Investments, Money at Call and Short Notice, Bank Nifty and Lending Rates. Accordingly, we frame the following quadratic equation.

$$
\mathbf{Y}_{\mathrm{t}}=\alpha+\boldsymbol{\beta}_{1} \mathbf{X}_{1 \mathrm{t}}+\ldots \ldots \ldots \ldots \ldots+\boldsymbol{\beta}_{\mathrm{n}} \mathbf{X}_{\mathrm{nt}}+\boldsymbol{\mu}
$$

Accordingly, Bank Credit can be better explained and estimated with the following version of equation. 
$\mathrm{BC}=f[\mathrm{AD}, \mathrm{INVEST}, \mathrm{MATCAL}, \mathrm{BORROW}, \mathrm{BNIFTY}, \mathrm{BPLR}]+\mu$

Due to potential nonlinearities, the natural logarithms of the regressors are considered accordingly, when we log-transform this model we obtain:

$$
\begin{aligned}
\operatorname{LnBC}=\alpha+ & \text { LnAD }+ \text { LnINVEST }+ \text { LnMATCAL }+ \text { LnBORROW }+ \text { LnBNIFTY }+ \\
& + \text { LnBPLR }+\mu
\end{aligned}
$$

We expect the borrowings to have a close positive relationship with the bank credit during the recession in view of the tight liquidity and decreasing deposits mobilization scenario. Further, we also predict that as the banks are guided by their profit seeking behaviour they tend to curtail their lending activity and try to invest their funds in the assured investments instead of venturing into the risky activity of lending.

\subsection{Methodology}

Given that we are dealing with time series data, the possibility of non-stationarity of the variables cannot be ruled out. We perform stationarity test on the variables that are included in our analysis to ensure that the results from the analysis are not spurious. For this purpose, Augmented Dickey Fuller (hereafter, ADF) test and Phillips and Perron (hereafter, PP) (1988) tests are conducted to know the stationarity of the variables.

$\Delta Y_{t}=\gamma Y_{t-1}+\sum_{i=2}^{p} \beta_{i} \Delta Y_{t-1}+1+\epsilon_{t}$

$\left(Y_{t}\right.$ is a pure random walk if $\left.\gamma=0\right)$

$\Delta Y_{t}=\alpha_{0}+\gamma Y_{t-1}+\sum_{i=2}^{p} \beta_{i} \Delta Y_{t-1}+1+\epsilon_{t}$

$\left(Y_{t}\right.$ is a random walk with drift if $\left.\gamma=0\right)$

Further,

$\Delta Y_{t}=\alpha_{0}+\gamma Y_{t-1}+\alpha_{2 t}+\sum_{i=2}^{p} \beta_{i} \Delta Y_{t-1}+1+\epsilon_{t}$

$Y_{t}$ is a random walk with a drift with linear time trend if $\gamma=0$. The ADF test mentioned above assumes that the errors are statistically independent and have a constant variance. In case of PP test, the assumption is relaxed, allows the error disturbances to be weakly dependent, and heterogeneously distributed.

This can be written as: 


$$
Y_{t}=\alpha_{0}+\alpha_{1} Y_{t-1}+\alpha_{2}\left(t-\frac{T}{2}\right)+\epsilon_{t}
$$

In both the tests the null hypothesis is that the series is non-stationary (possess a unit root) and if the calculated value exceeds the critical value (based on Mackinnon, 1996 for ADF and PP test), the null hypothesis may be rejected implying the stationary characteristics of the data series. The ADF test is a parametric auto regression to ARIMA structure of the errors in the test regression, but the PP test corrects for serial correlation and heteroscedasticity in the errors. In ADF test, Schwarz Information criteria (SIC) have been used to select the appropriate lag length, whereas in PP test we have used the Newey-West using Bartlet kernel method.

We use a Cointegration framework to identify systematic interaction effects between the identified determinants of lending behaviour of banks. Accordingly, Johansen's Cointegration technique was employed to verify the existence of cointegration between the determinants of bank credit and other determinants as mentioned above. Once the order of integration of each variable is determined in three periods, the concept of Cointegration by Johansen and Juselius (1990) method (hereafter JJ method) ${ }^{1}$ is used to examine the existence of cointegrating relationship between the determinants.

This method is considered to be more robust than the Engel Granger procedure (based the residual). Therefore, we prefer the JJ method, which uses the Vector Auto Regressive (VAR) model to test the number of cointegrating vectors, and the estimation is based on Maximum Likelihood (ML) method. Following Johansen (1988), Johansen, and Juselius (1990) VAR representation of column vector $X_{t}$ can be written as follows:

$$
X_{(t)}=B z_{t}+\sum_{i=1}^{k} \Pi_{i} X_{(t-i)}+\varepsilon_{t}
$$

Where $X_{t}$ is column vector of $n$ endogenous variables, $z$ is a $(n \times 1)$ vector of deterministic variables, $\varepsilon$ is a $(n \times 1)$ vector of white noise error terms, and $\Pi_{i}$ is a $(n \times n)$ matrix of coefficients. Since, most of the macroeconomic time series variables are non-stationary, VAR of such models are generally estimated in first-difference forms.

JJ test provides two Likelihood Ratio (LR) test statistics for cointegration analysis, the trace $\left(\lambda_{\text {trace }}\right)$ statistics, and the maximum eigenvalue $\left(\lambda_{\max }\right)$ statistics. The trace statistics tests

\footnotetext{
${ }^{1}$ See Philips(1991),Cheung and Lai(1993) and Gonzala (1994).
} 
the null hypothesis that the number of cointegrating relations is $r$ against $k$ cointegration relations, where $\mathrm{k}$ is the number of endogenous variables. The maximum eigenvalue test, tests the null hypothesis that there are $r$-cointegrating vectors against an alternative of $r+1$ cointegrating vectors. To determine the rank of matrix $\Pi$, the test values obtained from the two test statistics are compared with the critical value from Mackinnon-Haug-Michelis (1999). For both tests if the test statistic value is greater than the critical value, the null hypothesis of $r$ cointegrating vectors is rejected in favor of the corresponding alternative hypothesis.

\section{Analysis of Results}

Tables 3, 4 and 5 present the correlations statistics of the determinants employed in the analysis for the pre-recession period, recession period and recovery period. During the PreRecession period LnBC has strong positive correlations with; LnAD (0.983), LnINVEST (0.946), LnBORROW (0.811), LnBPLR (0.433) at 0.01\% level of significance (Table-3).

Table 3: Correlations statistics (pre-recession period)

\begin{tabular}{|l|c|c|c|c|c|c|c|}
\hline & LnAD & $\begin{array}{c}\text { LnBOR } \\
\text { ROW }\end{array}$ & $\begin{array}{c}\text { LnMAT } \\
\text { CAL }\end{array}$ & $\begin{array}{c}\text { LnINV } \\
\text { EST }\end{array}$ & $\begin{array}{c}\text { LnBNI } \\
\text { FTY }\end{array}$ & $\begin{array}{c}\text { LnBP } \\
\text { LR }\end{array}$ & LnBC \\
\hline LnAD & 1 & & & & & & \\
\hline LnBORROW & $.753^{* *}$ & 1 & & & & & \\
\hline LnMATCAL & $-.256^{*}$ & .113 & 1 & & & & \\
\hline LnINVEST & $.977^{* *}$ & $.728^{* *}$ & $-.295^{* *}$ & 1 & & & \\
\hline LnBNIFTY & $.319^{* *}$ & .041 & $-.328^{* *}$ & $.421^{* *}$ & 1 & & \\
\hline LnBPLR & $.514^{* *}$ & .184 & $-.284^{* *}$ & $.473^{* *}$ & $.372^{* *}$ & 1 & \\
\hline LnBC & $.983^{* *}$ & $.811^{* *}$ & -.162 & $.946^{* *}$ & $.215^{*}$ & $.433^{* *}$ & 1 \\
\hline
\end{tabular}

Table 4: Correlations statistics (recession period)

\begin{tabular}{|l|c|c|c|c|c|c|c|}
\hline & LnAD & $\begin{array}{c}\text { LnBOR } \\
\text { ROW }\end{array}$ & $\begin{array}{c}\text { LnMAT } \\
\text { CAL }\end{array}$ & $\begin{array}{c}\text { LnINV } \\
\text { EST }\end{array}$ & $\begin{array}{c}\text { LnBPL } \\
\text { R }\end{array}$ & $\begin{array}{c}\text { LnBNI } \\
\text { FTY }\end{array}$ & LnBC \\
\hline LnAD & 1 & & & & & & \\
\hline LnBORROW & $-.214^{*}$ & 1 & & & & & \\
\hline LnMATCAL & $-.723^{* *}$ & $.461^{* *}$ & 1 & & & & \\
\hline LnINVEST & $.980^{* *}$ & $-.241^{*}$ & $-.725^{* *}$ & 1 & & & \\
\hline LnBPLR & $-.863^{* *}$ & .138 & $.609^{* *}$ & $-.899^{* *}$ & 1 & & \\
\hline LnBNIFTY & $.788^{* *}$ & $-.406^{* *}$ & $-.775^{* *}$ & $.764^{* *}$ & $-.573^{* *}$ & 1 & \\
\hline LnBC & $.964^{* *}$ & -.135 & $-.659^{* *}$ & $.916^{* *}$ & $-.797^{* *}$ & $.698^{* *}$ & 1 \\
\hline
\end{tabular}


During the Recession period LnBC has strong positive correlations with; LnAD (0.964), LnINVEST (0.916), LnBNIFTY (0.698) at 0.01\% level of significance and has negative correlation with; LnMATCAL (-0.659) and LnBPLR (-0.797) at 0.01\% level of significance (Table 4). During the Recovery period LnBC has strong positive correlations with; LnAD (0.518), LnINVEST (0.728), LnBPLR (0.422), LnBNIFTY (0.426) at $0.01 \%$ level of significance and has negative correlation (Table 5).

Table 5: Correlation among variables (recovery period)

\begin{tabular}{|l|c|c|c|c|c|c|c|}
\hline & LnAD & $\begin{array}{c}\text { LnBOR } \\
\text { ROW }\end{array}$ & $\begin{array}{c}\text { LnMAT } \\
\text { CAL }\end{array}$ & $\begin{array}{c}\text { LnINV } \\
\text { EST }\end{array}$ & $\begin{array}{c}\text { LnBPL } \\
\text { R }\end{array}$ & $\begin{array}{c}\text { LnBNI } \\
\text { FTY }\end{array}$ & LnBC \\
\hline LnAD & 1 & & & & & & \\
\hline LnBORROW & .275 & 1 & & & & & \\
\hline LnMATCAL & $.363^{* *}$ & .179 & 1 & & & & \\
\hline LnINVEST & $.737^{* *}$ & $.357^{*}$ & -.004 & 1 & & & \\
\hline LnBPLR & $.970^{* *}$ & $.299^{*}$ & $.378^{* *}$ & $.645^{* *}$ & 1 & & \\
\hline LnBNIFTY & $.928^{* *}$ & $.356^{*}$ & $.383^{* *}$ & $.621^{* *}$ & $.942^{* *}$ & 1 & \\
\hline LnBC & $.518^{* *}$ & $.292^{*}$ & .255 & $.728^{* *}$ & $.422^{* *}$ & $.426^{* *}$ & 1 \\
\hline
\end{tabular}

Notes: ${ }^{* *}$ Correlation is significant at the 0.01 level (2-tailed). *Correlation is significant at the 0.05 level (2tailed).

Tables 6, 7 and 8 show the Augmented Dickey-Fuller (ADF 1979) Phillip Perron (PP 1988) unit-root test results. In both the tests, the null hypothesis is that the series is nonstationary (possess a unit root) and if the calculated value exceeds the critical value (based on Mackinnon, 1996 for ADF and PP test), the null hypothesis may be rejected implying the stationary characteristics of the data series.

Table-6: Stationarity test results (pre-recession period)

\begin{tabular}{|l|c|c|c|c|}
\hline \multirow{2}{*}{ Variables } & \multicolumn{2}{c|}{ At level Form } & \multicolumn{2}{c|}{ At First Difference form } \\
\cline { 2 - 5 } & ADF statistic & PP statistic & ADF statistic & PP statistic \\
\hline LnBC & -0.428456 & -0.431008 & $-8.908858^{*}$ & $-85.32742^{*}$ \\
\hline LnAD & -0.879530 & -1.457736 & $-10.29290^{*}$ & $-14.75445^{*}$ \\
\hline LnBORROW & -0.014152 & -0.084157 & $-8.8621298^{*}$ & $-79.40365^{*}$ \\
\hline LnMATCAL & -0.633163 & -0.557301 & $-10.14116^{*}$ & $-18.52506^{*}$ \\
\hline LnINVEST & -0.086942 & -0.086942 & $-8.833085^{*}$ & $-84.55829^{*}$ \\
\hline LnBNIFTY & -1.583966 & -1.627241 & $-10.06231^{*}$ & $-10.02447^{*}$ \\
\hline LnBPLR & -1.585209 & -1.628026 & $-10.06809^{*}$ & $-10.02983^{*}$ \\
\hline
\end{tabular}

Note: *Significant at 0.01 level.

The results revealed that all the level (first-differenced) variables are insignificant (significant) at the 0.01 percent level, indicating that all the variables during these three periods are integrated at the first degree and satisfied the condition for the cointegration test. 
Johansen (1988) and Johansen and Juselius (1990) developed this methodology (cointegration) for assessing long-run relationships. The methodology applies maximum likelihood procedure to determine the presence of cointegrating vectors in a set of nonstationary time series.

Table 7: Stationarity test results (recession period)

\begin{tabular}{|l|c|c|c|c|}
\hline \multirow{2}{*}{ Variables } & \multicolumn{2}{c|}{ At level Form } & \multicolumn{2}{c|}{ At First Difference form } \\
\cline { 2 - 5 } & ADF statistic & PP statistic & ADF statistic & PP statistic \\
\hline LnBC & -0.751725 & -0.609777 & $-12.23925^{*}$ & $-12.09305^{*}$ \\
\hline LnAD & -1.477376 & -1.379730 & $-13.04749^{*}$ & -15.385588 \\
\hline LnBORROW & -0.390756 & -0.390756 & $-9.981443^{*}$ & $-28.56700^{*}$ \\
\hline LnMATCAL & -1.232399 & -1.341713 & -10.120958 & $-23.34173^{*}$ \\
\hline LnINVEST & -1.478795 & -1.524909 & $-8.854521^{*}$ & $-12.67635^{*}$ \\
\hline LnBNIFTY & -0.692584 & -0.647832 & $-9.883277^{*}$ & $-9.883277^{*}$ \\
\hline LnBPLR & -1.346230 & -1.239941 & $-9.814503^{*}$ & $-9.818384^{*}$ \\
\hline
\end{tabular}

Note: *Significant at 0.01 per cent level.

Table 8: Stationarity test results (recovery period)

\begin{tabular}{|l|c|c|c|c|}
\hline \multirow{2}{*}{ Variables } & \multicolumn{2}{c|}{ At level Form } & \multicolumn{2}{c|}{ At First Difference form } \\
\cline { 2 - 5 } & ADF statistic & PP statistic & ADF statistic & PP statistic \\
\hline LnBC & -0.358440 & -0.206328 & $-9.194190^{*}$ & $-9.422216^{*}$ \\
\hline LnAD & -0.556997 & -0.185782 & $-7.233743^{*}$ & $-10.03406^{*}$ \\
\hline LnBORROW & -0.977743 & -0.977743 & $-7.495562^{*}$ & $-11.73249^{*}$ \\
\hline LnMATCAL & -0.602755 & -0.638488 & $-6.936360^{*}$ & $-9.765911^{*}$ \\
\hline LnINVEST & -2.854436 & -2.672870 & $-8.378243^{*}$ & $-9.334602^{*}$ \\
\hline LnBNIFTY & -1.467749 & -1.365785 & $-8.533983^{*}$ & $-8.471221^{*}$ \\
\hline LnBPLR & 0.324520 & 0.116450 & $-9.466734^{*}$ & $-9.472437^{*}$ \\
\hline \multicolumn{2}{|l|}{ Note: * Significant at 0.01 per cent level. }
\end{tabular}

As the number of lag orders selected can affect the number of cointegration, the appropriate lags are carefully selected with a number of multivariate diagnostic tests. The appropriate lag orders can be selected from five information criteria (i.e., the likelihood ratio, the Final Prediction Error (FPE), the Akaike Information Criterion (AIC), the Schwarz Information Criterion (SIC), and the Hannan Quinn Information Criterion (HQIC)) are first determined. For doing cointegration, the study selected lag interval of one (for all three models) as suggested by Schwarz Information criteria (SIC). In this study, both trace and maximum eigenvalue statistics are considered in determining the number of cointegration vectors. In particular, if two test statistics show the same number of cointegration, that number is used. If two statistics do not show the same number of cointegration, the number is 
selected using trace test. Luintel and Khan (1999) have shown that trace test is more robust than maximum eigen value criteria in testing the cointegration.

Having confirmed that integration of the seven series is of the same order (checked for three periods); we test whether the seven series are cointegrated over the sample period. The numbers in the tables 9, 10 and 11 show the results of the Johansen test. Since the Johansen test is based on vector auto regressive model (VAR), we select one period lag for the model based on SIC. Starting with the null hypothesis of no cointegration among the variables, trace statistics is 220.6801, which is well above the 0.05 critical value. Thus, we reject the null hypothesis of no cointegration among these variables at 0.05 and accept that there is one cointegrating equation.

Considering the null hypothesis of at most one co-integrating relation, based on the trace statistics of 131.3113 , which is greater than 0.05 critical value of 83.93712 we reject the null hypothesis of at most one co-integrating equation at 0.05 significance level. Similar is the case with the second and third cointegration relationship, where we find trace statistics is greater than the critical value thus we reject the null hypothesis and infer that there are more than three cointegrating relationship between variables.

Table 9: Results of cointegration analyses (pre-recession period)

\begin{tabular}{|c|c|c|c|c|}
\hline \multicolumn{5}{|c|}{ Unrestricted Cointegration Rank Test (Trace) } \\
\hline Hypothesized & & Trace & 0.05 & \\
\hline No. of CE(s) & Eigenvalue & Statistic & Critical Value & Prob.** \\
\hline None $^{*}$ & 0.650551 & 220.6801 & 111.7805 & 0.0000 \\
\hline At most $1 *$ & 0.418264 & 131.3113 & 83.93712 & 0.0000 \\
\hline At most $2 *$ & 0.326852 & 85.26360 & 60.06141 & 0.0001 \\
\hline At most $3 *$ & 0.313520 & 51.62147 & 40.17493 & 0.0024 \\
\hline \multicolumn{5}{|c|}{$\begin{array}{c}\text { Unrestricted Cointegration Rank Test (Maximum Eigenvalue) } \\
\end{array}$} \\
\hline Hypothesized & & Max-Eigen & 0.05 & \\
\hline No. of CE(s) & Eigenvalue & Statistic & Critical Value & Prob.** \\
\hline None $*$ & 0.650551 & 89.36884 & 42.77219 & 0.0000 \\
\hline At most $1 *$ & 0.418264 & 46.04771 & 36.63019 & 0.0030 \\
\hline At most $2 *$ & 0.326852 & 33.64212 & 30.43961 & 0.0193 \\
\hline At most $3 *$ & 0.313520 & 31.97512 & 24.15921 & 0.0036 \\
\hline
\end{tabular}

The result from Maximum Eigen Statistics table also supports that there is more than three cointegrating relationship. In addition, we find that Maximum Eigen value is greater than the 
critical value and hence we reject the null hypothesis of at most three cointegration vectors at 0.05 per cent level of significance. Hence based on trace test we may conclude that there are more than three co-integrating equation among these variables during pre-recession.

In the similar vein, the statistics in Table 10 shows the cointegrating relationship between the study variables during recession. In this case, both statistics (trace and maximum eigenvalue) are showing similar results. The trace statistics of 60.93088, which is greater than the critical value (54.07904) at $5 \%$ level of significance (see at most two). Therefore, we are rejecting the null hypothesis that there are at most two cointegrating vectors and may accept the alternative hypothesis of more than two cointegrating relationship among variables.

Table 10: Results of cointegration analyses (recession period)

\begin{tabular}{|c|c|c|c|c|}
\hline \multicolumn{5}{|c|}{ Unrestricted Cointegration Rank Test (Trace) } \\
\hline Hypothesized & & Trace & 0.05 & \\
\hline No. of CE(s) & Eigenvalue & Statistic & Critical Value & Prob.** \\
\hline None * & 0.457913 & 191.9675 & 134.6780 & 0.0000 \\
\hline At most $1 *$ & 0.410861 & 139.9196 & 103.8473 & 0.0000 \\
\hline At most $2 *$ & 0.329805 & 94.94674 & 76.97277 & 0.0011 \\
\hline At most $3 *$ & 0.292357 & 60.93088 & 54.07904 & 0.0108 \\
\hline \multicolumn{5}{|c|}{ Trace test indicates 4 cointegrating eqn(s) at the 0.05 level } \\
\hline \multicolumn{5}{|c|}{ Unrestricted Cointegration Rank Test (Maximum Eigenvalue) } \\
\hline Hypothesized & & Max-Eigen & 0.05 & \\
\hline No. of CE(s) & Eigenvalue & Statistic & Critical Value & Prob.** \\
\hline None $*$ & 0.457913 & 52.04788 & 47.07897 & 0.0135 \\
\hline At most $1 *$ & 0.410861 & 44.97290 & 40.95680 & 0.0168 \\
\hline At most $2 * *$ & 0.329805 & 34.01586 & 34.80587 & 0.0619 \\
\hline At most $3 *$ & 0.292357 & 29.39427 & 28.58808 & 0.0394 \\
\hline
\end{tabular}

Notes: $*$ and $* *$ denote rejection of the hypothesis at the 0.05 and 0.10 levels.

Cointegrating relationship among variables during recovery period is shown in the Table 11. From these results, it is found that there is more than one cointegrating relationship (based on trace test). In case of trace test, the statistic is greater than the critical value at 0.05 level of significance and rejecting the null hypothesis of at most one cointegrating relationship. However, in case of maximum eigen value criteria it found that there is one co-integrating relationship. However, based on Luintel and Khan (1999) suggestion the study preferred trace test and inferred that there is more than one cointegrating relationship among study variables during recovery period. 
Table 11: Results of cointegration analyses (recovery period)

\begin{tabular}{|c|c|c|c|c|}
\hline \multicolumn{5}{|c|}{ Unrestricted Cointegration Rank Test (Trace) } \\
\hline Hypothesized & & Trace & 0.05 & \\
\hline No. of CE(s) & Eigenvalue & Statistic & Critical Value & Prob.** \\
\hline None $*$ & 0.699329 & 173.7180 & 134.6780 & 0.0000 \\
\hline At most $1 *$ & 0.539903 & 114.8329 & 103.8473 & 0.0077 \\
\hline At most 2 & 0.447989 & 76.79325 & 76.97277 & 0.0516 \\
\hline \multicolumn{5}{|c|}{ Trace test indicates 2 cointegrating eqn(s) at the 0.05 level } \\
\hline \multicolumn{5}{|c|}{ Unrestricted Cointegration Rank Test (Maximum Eigenvalue) } \\
\hline Hypothesized & & Max-Eigen & 0.05 & \\
\hline No. of CE(s) & Eigenvalue & Statistic & Critical Value & Prob.** \\
\hline None ${ }^{*}$ & 0.699329 & 58.88519 & 47.07897 & 0.0018 \\
\hline At most 1 & 0.539903 & 38.03960 & 40.95680 & 0.1028 \\
\hline At most 2 & 0.447989 & 29.11518 & 34.80587 & 0.2042 \\
\hline \multicolumn{5}{|c|}{ Max-eigenvalue test indicates 1 cointegrating eqn(s) at the 0.05 level } \\
\hline
\end{tabular}

The normalized cointegration coefficients for the three models are presented in Table 12.

Table 12: Normalized cointegrating coefficients

\begin{tabular}{|l|c|c|c|}
\hline $\begin{array}{c}\text { LnBC as Endogenous } \\
\text { Variable }\end{array}$ & $\begin{array}{c}\text { Pre-recession } \\
\text { period }\end{array}$ & Recession period & $\begin{array}{c}\text { Recovery } \\
\text { period }\end{array}$ \\
\hline LnAD & $0.848912^{*}$ & $2.617435^{*}$ & $3.384583^{*}$ \\
\hline LnBORROW & $(0.13895)$ & $(0.79629)$ & $(0.34804)$ \\
\hline & $-0.650012^{*}$ & $1.177967^{*}$ & $0.176190^{*}$ \\
\hline LnMATCAL & $(0.07507)$ & $(0.21337)$ & $(0.06679)$ \\
\hline & $0.151451^{*}$ & 0.007027 & $-0.069528^{*}$ \\
\hline LnINVEST & $(0.02822)$ & $(0.06319)$ & $(0.02058)$ \\
\hline & $0.72162)^{*}$ & $-2.775382^{*}$ & $-5.015145^{*}$ \\
\hline LnBNIFTY & $(0.07062)$ & $(0.63232)$ & $(0.52197)$ \\
\hline LnBPLR & $-7.149430^{*}$ & $0.334245^{*}$ & $0.331396^{*}$ \\
\hline & $(1.08430)$ & $(0.08295)$ & $(0.05755)$ \\
\hline Constant & $22.54094^{*}$ & $-2.087602^{*}$ & $-0.677602^{*}$ \\
\hline & $(2.87292)$ & $(0.55803)$ & $(0.29096)$ \\
\hline
\end{tabular}

Notes: Figures in parentheses in normalized co integrating vectors are Standard errors.

* denotes statistical significance at 0.01 level level.

The signs of the coefficients like LnBORROW and LnBNIFTY were found to be negative and others are positive during pre-recession (see first column in Table 12). The results show that all the variables are significant. We thus infer that bank credit increases with increase in 
LnAD, LnINVEST, LnMATCAL and LnBPLR and decreases with an increase in LnBORROW and LnBNIFTY during pre-recession period.

During recession (see Table 12, column 2), the results show that, except LnMATCAL, all other variables are significant. For $\operatorname{LnAD}$ the coefficient is 2.61, signifying that its 0.01 level increase during recession led to more than 2.6 per cent increase in bank credits. In the same way the coefficients for LnBORROW, LnINVEST, LnBNIFTY are 1.17, -2.27(inverse relationship), 0.33 and -2.08(inverse relationship) respectively.

During recovery period (see Table 12 column 3), the variables (LnAD, LnBORROW, and LnBNIFTY) were found to be positively significant indicating that the increase in these variables led to a positive significant increase in bank credits during recovery period. The results show that during this period, LnMATCAL, LnINVEST, and LnBPLR had an inverse or negative relationship with bank credit, explaining the decrease in these factors.

\section{Conclusions}

This paper contributes uniquely to the evolving body of literature on bank's lending behavior during times of financial instability/uncertainty, which mostly prevails during the times of financial crises. Our findings provides answers to the oft-repeated question "What makes the banks squeeze their lending activity during the crisis?”. Broadly, our results are in agreement with the stylized facts on bank behavior in the recent financial crisis, especially on reduced bank lending, increased competition for retail deposits, and reduced monetary policy effectiveness.

We have found that, during the times of recession, particularly in the emerging markets of India, borrowings by banks have a significant positive relationship on the lending behavior of the banks. This is because of the fact that banks are unable to garner the much needed financial resources for lending through deposits in view of the prevailing factors of uncertainty/instability (during recession) which makes the depositors withhold their deposits. Instead depositors look for other real asset investments or to hold cash till the re-appearance of the signs of financial stability in the markets. 
Our study has also established that lending rates, even though they were downward during the recession period, were not having positively significant relationship with banks' lending. This elucidates that the lending rates were required to be reduced drastically in order to infuse bank lending. Further, results indicate that investment activity of the banks had a negatively significant relationship with bank lending. The reason is that during the times of financial instability, the banks tend to tighten their lending activity by stringent screening and rigorous monitoring of their borrowers, thereby increase their investments only if it ensures safe returns (profit-seeking behavior and also due to the fall in the state of confidence of banks and the nature of firm decision structures). This can be discerned from the fact that, while Credit to Deposit Ratio showed a downward trend, Investment to Deposit Ratio showed an upward trend during the recession evidencing the era of shortened lending activity of the banks. Further, we also notice decreasing Cash to Deposit Ratio during recession period which indicates the tight liquidity scenario in view of the financial instability and uncertainty.

We are of the view that failure to curb this trend of sharp decline in bank lending further results in banking crisis (Gentler 2010). Accordingly, we suggest that the bank's lending could be maintained at the relatively same pace during the times of recession too by increasing the borrowings rapidly either from the Central Banks or from Government supported long term lending institutions. Besides, this measure would also enable the banks to tide over the liquidity crisis that resulted out of the financial crisis.

Author Information: Vigneshwara Swamy is a professor at the Indian Business School, Hyderabad, India. He may be reached via E-mail: vswamypm@gmail.com or Phone: 91-970509-6919. The co-author is S. sreejesh: E-mail: sreejeshibs@gmail.com

\section{References}

Allen, F., And Carletti, E., (2010). An Overview of the Crisis: Causes, Consequences, and Solutions, International Review of Finance, 10:1: 1-26.

Brunnermeier, M., (2009). Deciphering the liquidity and credit crunch 2007-08, Journal of Economic Perspectives, 23, 77-100.

Calomiris, C.W., and B. Wilson (2004). Bank capital and portfolio management: The 1930s "capital crunch" and the scramble to shed risk, Journal of Business, 77(3), 421-454.

Cheung, Y W and Lai, K.S., (1993). Finite sample sizes of Johanson's likelihood ratio test for Cointegration, Oxford Bulletine for Economics and Statistics, 55,313-28.

De Haas, R.T.A., and I.P.P. Van Lelyveld (2006). Foreign banks and credit stability in Central and Eastern Europe: A panel data analysis, Journal of Banking and Finance, 30, 1927-1952. 
Dickey, D. and W. Fuller, (1979). Distribution of the estimators for autoregressive time series with a unit root, Journal of the American Statistical Association 84, 427-431.

Demirgüç-Kunt, A., E., Detragiache and P. Gupta (2006). Inside the crisis: an empirical analysis of banking systems in distress, Journal of International Money and Finance, 25, 702-718.

Gertler, M., (2010). Banking Crises and Real Activity: Identifying the Linkages, International Journal of Central Banking, Vol. 6 No. 4, December.

Gonzalo, J., (1994). Five alternative methods of estimating long-run equilibrium Relationships, Journal of Econometrics, 60(1-2), 203-233.

Greenlaw, D., Hatzius, J., Kashyap, A., and Shin, H., (2008). Leveraged losses: lessons from the mortgage market meltdown, U.S. Monetary Policy Forum, Report no. 2: 7-59.

Ivashina, V. and D. Scharfstein (2008). Bank lending during the financial crisis of 2008, Mimeo.

Johansen, S., (1988). Statistical analysis of cointegration vectors, Journal of Economic Dynamics and Control 12, 231-254.

Johansen, Soren and Juselius, Katarina, (1990). Maximum Likelihood Estimation and Inference on Cointegration-With Applications to the Demand for Money, Oxford Bulletin of Economics and Statistics, Department of Economics, University of Oxford, vol. 52(2), pages 169-210, May.

MacKinnon, J. G., (1996). Numerical distribution functions for unit root and cointegration tests, Journal of Applied Econometrics, 11, 601-618.

MacKinnon J.G,, Alfred Haug, and Leo Michelis (1999). Numerical Distribution Functions of Likelihood Ratio Tests for Cointegration, Journal of Applied Econometrics, Vol. 14, No. 5, 1999, pp. 563-577.

Mishkin, F. (1999a). Global financial instability: framework, events, issues, Journal of Economic Perspectives, 13(4), fall: 3-20.

Mishkin, F. (1999b). Lessons from the Asian crisis, Journal of International Money and Finance, 18: 709-723.

Ongena, S., (1999). Lending relationships, bank default, and economic activity, International Journal of the Economics of Business, 6(2), 257-280.

Phillips, P.C.B., and P. Perron (1988), Testing for a unit root in time series regression, Biometrika 7.5, 335-346.

Phillips, P. C. B. (1991). Optimal inference in cointegrated systems, Econometrica, Vol.50, pp.283-306.

Ralph de Haas and Neeltje van Horen, (2009). The strategic behavior of banks during a financial crisis; evidence from the syndicated loan market, European Bank for Reconstruction and Development (EBRD), Central Bank of the Netherlands (DNB) Retrieved from; at http://mpra.ub.uni-muenchen.de/14164/ MPRA Paper No. 14164

Rajan, R.G. (1992). Insiders and outsiders: the choice between informed and arm's-length debt, Journal of Finance, 47, 1367-1400.

Taylor, J., (2008). The financial crisis and the policy responses: an empirical analysis of what went wrong, Working Paper, Stanford University. 